\title{
Species and size selectivity in a 'red' sea bream longline 'métier' in the Algarve (southern Portugal)
}

\author{
Karim Erzini ${ }^{(*)}$, Jorge M.S. Gonçalves, Luís Bentes, Pedro G. Lino, Joaquim Ribeiro \\ Unidade de Ciências e Tecnologias dos Recursos Aquáticos (UCTRA), Campus de Gambelas, Universidade do Algarve, \\ 8000 Faro, Portugal.
}

Received August 1, 1997; accepted December 22, 1997.

\begin{abstract}
A longline 'métier' using small hooks for 'red' sea breams (Pagellus acarne and Pagellus erythrinus) in the Algarve (south of Portugal) was studied. Experimental longlining was carried out with three sizes of "Mustad" round bend, flatted, spade end Quality 2316 DT hooks (numbers 11,13 and 15) and two types of bait: razor shell (Ensis siliqua) and mud shrimp (Upogebia pusilla). A total of 3328 fish and at least 36 species were caught with 33600 hooks fished in 28 longline sets. Five species of sea breams (Sparidae) accounted for $79 \%$ of the catch: Pagellus acarne, Pagellus erythrinus, Diplodus vulgaris, Spondyliosoma cantharus, and Boops boops. High catch rates of 20-30 fish per 100 hooks were made in a number of 1200 hook longline sets, with total catch weights of 40 to more than $60 \mathrm{~kg}$ per set. In general, the smallest hook (number 15) had the highest catch rate. Bait type did not significantly affect the catch size distributions. Although more fish were caught with the razor shell bait, higher catch rates of 'red' sea breams were obtained with mud shrimp. Catch rates were also affected by the location of the fishing grounds and the time of the set, with the highest catch rates obtained when the longline was set within two hours before sunrise. A wide size range was caught for each species, with highly overlapped catch size frequency distributions for the three hook sizes used. Except for Spondyliosoma cantharus, few illegal-sized fish were caught, even with the smallest hook. The logistic model fitted by maximum likelihood was used to describe hook selectivity for Diplodus vulgaris, Pagellus acarne, Pagellus erythrinus, and Spondyliosoma cantharus. $\odot$ IfremerElsevier, Paris
\end{abstract}

hook / longline / gear selectivity / artisanal fisheries / sea bream / Sparidae / Diplodus vulgaris / Pagellus acarne / Pagellus erythrinus / Spondyliosoma cantharus

Résumé - Sélectivité des espèces et des tailles des pageots (Sparidés) capturés au moyen de palangres sur les côtes de l'Algarve (Sud Portugal). L'efficacité de palangres munies d'hameçons de petite taille pour la pêche aux pageots de dorades roses (Pagellus acarne et Pagellus erythrinus) sur les côtes de l'Algarve (Sud Portugal) a été étudiée. Des palangres expérimentales ont été mises au point avec 3 tailles d'hameçons de type "Mustad ", courbe à palette aplatie et de qualité 2316 DT (numéros 11, 13 et 15) avec deux types d'appât : des couteaux (Ensis siliqua) et des crevettes (Upogebia pusilla). Un total de 3328 poissons, d'au moins 36 espèces, a été capturé avec 28 séries de palangres, soit 33600 hameçons. Cinq espèces de Sparidés ont été capturées, représentant $70 \%$ des prises : Pagellus acarne, Pagellus erythrinus, Diplodus vulgaris, Spondyliosoma cantharus et Boops boops. De forts taux de capture, de 20 à 30 poissons pour 100 hameçons ont été réalisés sur des séries de palangres de 1200 hameçons, avec un poids total de 40 à plus de $60 \mathrm{~kg}$ par série. En général, les plus petits hameçons (numéro 15) ont eu les taux de capture les plus élevés. Le type d'appât n'affecte pas de façon significative la répartition par taille des captures. Bien que davantage de poissons aient été capturés avec des couteaux comme appâts, les taux de capture étaient plus élevés avec des crevettes. Les taux de capture dépendent aussi des zones et de l'heure de pêche ; les taux de captures les plus élevés ont été obtenus lorsque les palangres étaient posées 2 heures avant le lever du soleil. Une gamme étendue de tailles pour chaque espèce a été observée dans les captures, avec des répartitions en tailles se superposant pour les 3 types d'hameçon. A l'exception de Spondyliosoma cantharus, peu de poissons de taille illégale ont été capturés, même avec l'hameçon le plus petit. L'ajustement d'un modèle logistique, avec le maximum de vraisemblance, a été utilisé pour décrire la sélectivité pour les captures de Diplodus vulgaris, Pagellus acarne, Pagellus erythrinus et Spondyliosoma cantharus. (C) Ifremer-Elsevier, Paris

hameçon / palangre / sélectivité des engins de pêche / pêche artisanale / pageot / Sparidés / Diplodus vulgaris / Pagellus acarne / Pagellus erythrinus / Spondyliosoma cantharus

${ }^{(*)}$ Corresponding author (e-mail: kerzini@ ualg.pt) 


\section{INTRODUCTION}

Longlines are an important gear in many European Union countries. Along the south coast of Portugal (the Algarve) for example, of 4202 commercial fishing licences issued in 1993, $1300(31 \%)$ were for longline gear. Even the smallest fishing boats may set longlines with 1 000-4 000 or more hooks. As typically 10$30 \%$ of hooks set are successful in catching fish (pers. obs.), longline gears may contribute significantly to fishing mortality, particularly for high value species such as sea bream (Sparidae), hake (Merluccius merluccius), and wreckfish (Polyprion americanus). Bottom longlines are widely used at depths ranging from less then 10 to more than $500 \mathrm{~m}$. In some fishing ports near fishing grounds which consist largely of rocky bottom, longlines are the dominant gear.

Although hook selectivity and factors affecting selectivity and catch rates have been extensively studied in Japan and in Scandinavian countries [2], there have been few corresponding studies in southern Europe or the Mediterranean. Along the south coast of Portugal four main longline 'métiers' have been identified. These are: (a) 'small' hook (generally sizes 1411) longlines for inshore sea breams, (b) 'small' hook longlines for deeper water 'red' sea breams, (c) 'large' hook (generally sizes 10-5) for large demersals such as Pagrus pagrus, Dentex gibbosus, Conger conger, and Polyprion americanus, and (d) the hake semi-pelagic 'pedra e bola' longline.

The first métier (a) was studied previously [7, 8, 9, 10]. The current study focused on the second 'small hook' longline métier (b) which uses longline gear identical to that used in the first, but differs from the first in fishing depth, fishing grounds, time of day, and target species [11]. This métier targets the axillary sea bream (Pagellus acame) and the common pandora (Pagellus erythrinus). These high value species are an important component of the Algarve landings.
The longline gear consists of a monofilament mainline of 1.0 or $1.1 \mathrm{~mm}$ diameter, with $75-100 \mathrm{~cm}$ gangions of $0.5 \mathrm{~mm}$ monofilament spaced $1.5-2.0 \mathrm{~m}$. The most commonly used hook is the number 13 round bend, spade end, Mustad brand hook. Various baits are used, with the most common being razor shell (Ensis siliqua) and mud shrimp (Upogebia sp.). This is for the most part a night fishery at depths from 40 to $70 \mathrm{~m}$.

The objectives of this study were: to obtain quantitative information on the catches of small hook longlines in this "red" sea bream fishery, to estimate the selectivity parameters for the most important species (in particular Pagellus acarne and Pagellus erythrinus, and to investigate some of the factors which affect the catch rates of these artisanal longlines.

\section{MATERIALS AND METHODS}

After consultation with Praia de Faro fishermen, we decided to use three different hook sizes (numbers 15 , 13 and 11) for the selectivity study. The dimensions of these round bent, flatted spade end hooks ('Mustad' brand Quality 2316 DT) are given in figure 1. Using

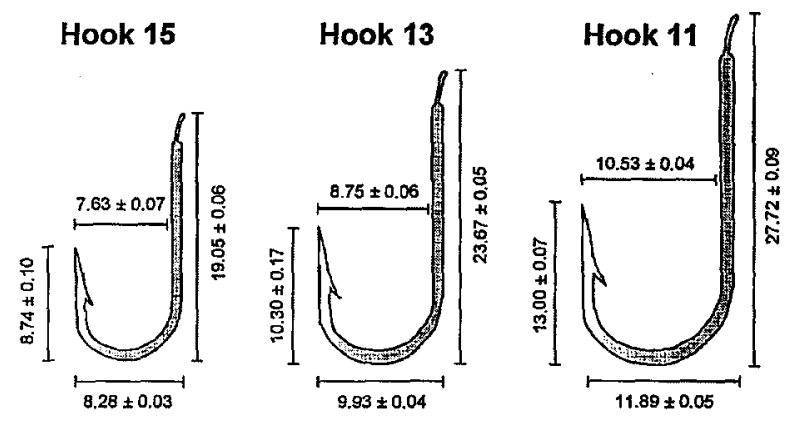

Figure 1. Shape and dimensions of each type of hook (numbers 11, 13 and 15) used in the selectivity study. Means and standard errors (in $\mathrm{mm}$ ) are based on a sample size of 10 hooks for each type.

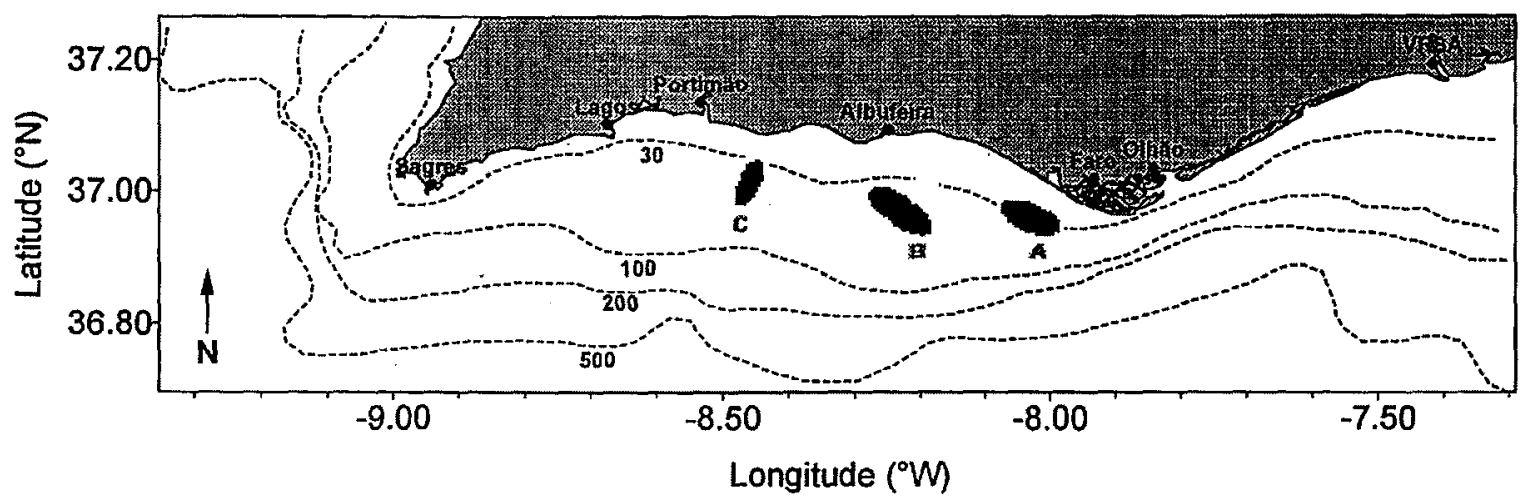

Figure 2. Map showing the south of Portugal and the location of the fishing grounds for fishing trials A, B and C. Depth contours are in metres. 
maximum width $\times$ maximum length to represent overall size, hooks number 13 and 11 are 1.49 and 2.09 times the size of the number 15 hook, respectively. A longline with 1200 hooks was made (four tubs). Each tub of 300 hooks contained 100 hooks of each size. The mainline was a $1.1 \mathrm{~mm}$ diameter monofilament and the gangions were $0.5 \mathrm{~mm}$ monofilament. Gangion lenght was $75 \mathrm{~cm}$, with a spacing of approximately $1.5 \mathrm{~m}$

Fishing operations were carried out using $6 \mathrm{~m}$ boats with 60 hp outboard engines launched either from the Praia de Faro beach or the Vilamoura marina. Two different boats were used and each fished in a different area: the first fished in front of the Praia de Faro (fishing trials A); the second more to the west (fishing trials $B$ and $C$ ). The longline was usually set at night, $1-2 h$ before dawn, and retrieved after an interval of less than $1 \mathrm{~h}$. The fishing grounds were at $45-55 \mathrm{~m}$ depths approximately $6-9 \mathrm{~km}$ offshore (figure 2 ).

Fishing trial A resulted in 19200 hooks being fished. Fourteen of the longline sets were before or just after sunrise, while one of the longline sets was during the day and the other was inshore targeting Pagrus pagrus. These two longline sets were not very productive and thus we did not repeat these fishing strategies.

A total of 20 longline sets (fishing trials A and B) were made using only razor shell bait and 8 longline sets $(\mathrm{C})$ were made with half the hooks of each size baited with mud shrimp (Upogebia sp.).

The three fishermen in each boat were always accompanied by at least one member of the project team. Depth, bottom and surface water temperature, and salinity were recorded. A global positioning system (GPS) was used to record the location of each set. Catches were separated by hook size and in the case of fishing trial $\mathrm{C}$, also by bait type. In the case of fishing trial $A$ the entire catch was taken to the laboratory. In fishing trial $\mathrm{B}$ and $\mathrm{C}$ the fish were measured at the landing site.

The plausibility of different selectivity models was investigated by means of exploratory plots of the observed catch proportion $\left(\mathrm{C}_{2}(l) /\left(\mathrm{C}_{1}(l)+\mathrm{C}_{2}(l)\right)\right.$ against size class $(l)$, where $C_{2}(l)$ is the catch of the larger size of hook [19]. Although the results clearly suggested logistic selectivity curves for Diplodus vulgaris and Spondyliosoma cantharus, the interpretation of the plots for the other two species was not conclusive. Thus, it was decided to fit both logistic and normal selectivity curves to all the species:

$$
s_{i j}=\frac{1}{1+\exp ^{-b_{i}\left(l_{j}-L 50_{i}\right)}}
$$

where $s_{i j}$ is the selectivity for hook size $i$ and size class $j, b_{i}$ is a parameter determining the slope of the selec- tivity curve for hook size $i$ and $L 50_{i}$ is the length at $50 \%$ selection

Normal:

$$
s_{i j}=\frac{1}{S_{i} \times \sqrt{2 \pi}} \times \exp \left\{\left(l_{j}-L_{i}\right)^{2} / 2 S_{i}^{2}\right\}
$$

where $S_{i}$ and $L_{i}$ are respectively the standard deviation and the mean length of the selectivity curve for hook size $i$.

Since equal fishing power of different hook sizes can not be assumed, selectivity models with a scaling factor $\left(Q_{i}\right)$ which is a linear or polynomial function of hook size were also fitted:

$$
s_{i j}=\frac{Q_{i}}{S_{i} \times \sqrt{2 \pi}} \times \exp \left\{\left(l_{j}-L_{i}\right)^{2} / 2 S_{i}^{2}\right\}
$$

The Kolmogorov-Smirnov test was used to test if there were significant differences in the catch size distributions due to the bait (razor shell or ghost shrimp) [26].

The methodology of Wulff [28] and Kirkwood and Walker [16] was used to estimate the parameters of selectivity curves. It is assumed that the parameters of the selectivity curve are a function of hook size. In our case maximum hook size (max. width $\times$ max. length) was used and the paramters of logistic and normal selectivity curves were modelled as linear and polynomial functions of maximum hook size $[7,8]$ :

$$
\begin{gathered}
\text { parameters } \\
\left(b_{i}, L 50_{i}, S_{i}, L_{i}\right)=\left(a \times H_{i}\right)+c \\
\text { parameters } \\
\left(b_{i}, L 50_{i}, S_{i}, L_{i}\right)=\left(a \times H_{i}\right)+\left(b \times H_{i}^{2}\right)+c
\end{gathered}
$$

where $a, b$, and $c$ are parameters of the linear and polynomial functions, and $H_{i}$ is the maximum size for hook number $i$.

The parameters of the selectivity curve can be estimated by maximising the following likelihood function [28]:

$$
\sum_{l, m}\left[C_{l, m} \times \log \left(S_{l, m} / \sum_{m} S_{l, m}\right)\right]
$$

where $C_{l, m}$ and $S_{l, m}$ are the catches and the selectivities for size classes $l$ and hook sizes $m$.

The Monte-Carlo multi-stage optimisation method of Saila and Erzini [25] was used to obtain initial (starting) parameter values for the non-linear maximis- 
Table I. Catch by hook number from 28 long-line sets (33 600 hooks), n, the number of fish; L (cm), the mean total length; S.D., standard deviation of total length.

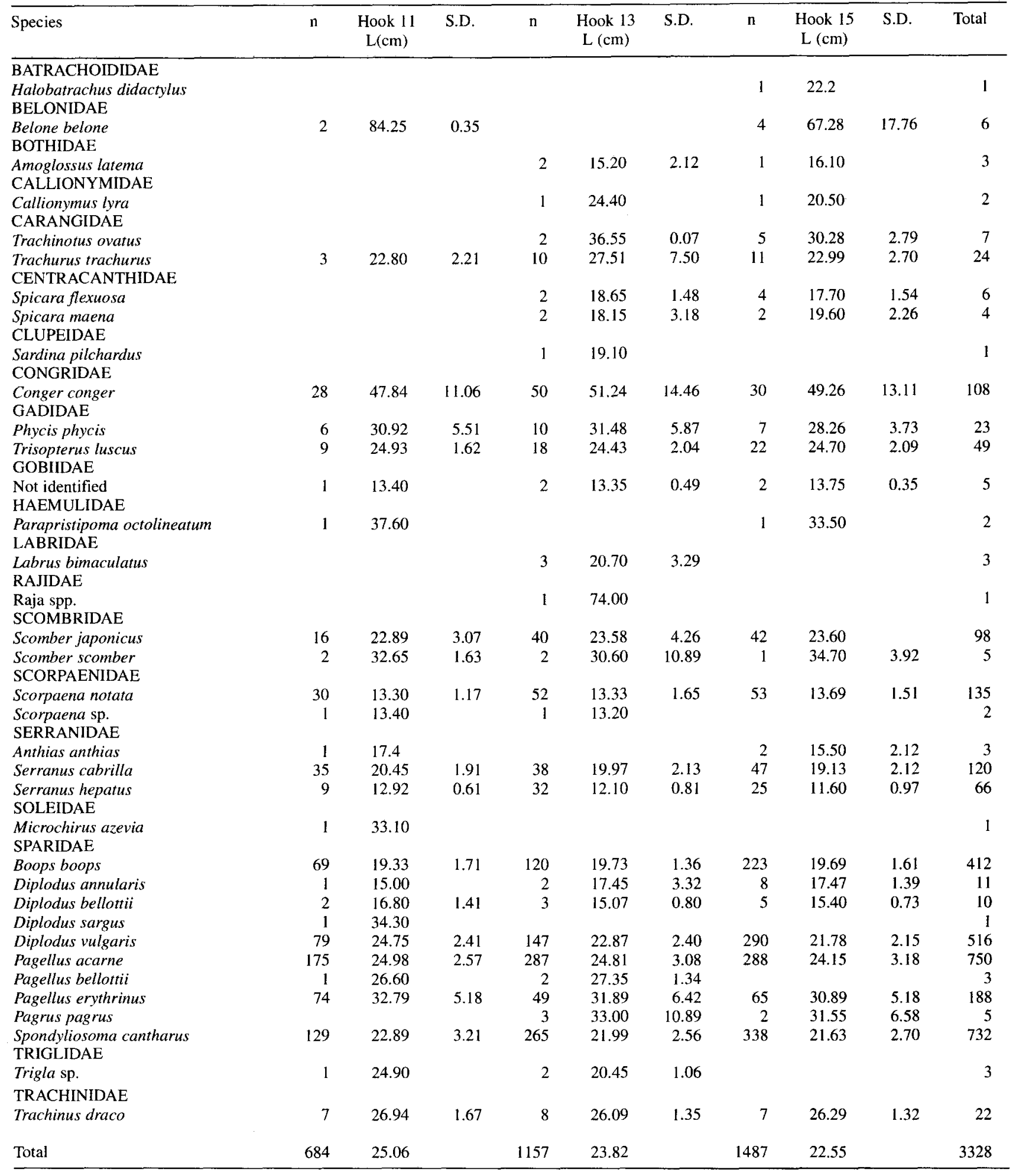

ation of the likelihood function. The NLP Procedure in SAS [12], implementing quasi-Newton optimisation algorithms with linear constraints was used to estimate the parameters and approximate standard errors. 
A $\chi^{2}$ test was used to compare observed and expected catches. Expected catches are calculated from the following relationship:

$$
\hat{C}_{l, m}=\hat{N}_{l} \times S_{l, m}=\left(\sum_{m} C_{l, m} / \sum_{m} S_{l, m}\right) \times S_{l, m}
$$

The expected catches of less than 5 at the tail end of each distribution were grouped in order to give minimum size class frequencies of 5 [28]. The observed $\chi^{2}$ value was compared with $\chi_{c-r-v, 0.05}^{2}$ where $c$ is the number of pairs of observed and expected values, $r$ is the number of size classes and $\mathrm{v}$ is the number of parameters in the model.

\section{RESULTS}

The results of the experimental longline fishing are summarised in table I. A total of 3328 fish were caught for 33600 hooks fished. At least 36 species were caught, with Sparidae dominating the catches in number of species, numbers, and weight. Five Sparidae (Boops boops, Diplodus vulgaris, Pagellus acarne, Pagellus erythrinus, Spondyliosoma cantharus) accounted for $79 \%$ of the catch.

Catch rates (number of fish per 100 hooks) decreased with increasing hook size; $13.3,10.3$ and 6.1 for hook sizes 15,13 , and 11 respectively. The largest hook size (number 11) also caught fewer species (26) compared to the smaller hooks, 30 and 28 species respectively for hooks 13 and 15 .

The catches per set of the four most important species are given in table II. The 'red' sea breams contributed up to $75.5 \%$ of the catch by weight pet set. However, catches of 'red' sea breams varied considerably and in some sets none were caught. Fishing trials $\mathrm{B}$ and C resulted in 14400 hooks being fished and again the two 'red' sea breams dominated the catches by weight $(52 \%)$ (table II). However, catch rates in fishing trials $\mathrm{B}$ and $\mathrm{C}$ were much higher than in fishing trial A. The overall catch rate was 19.3 with 27.5 for

Table II. Catches in numbers and weight (g) by hook size in fishing trials A, B, and C for the two 'red' sea breams (Pagellus acarne and Pagellus erythrinus), the two-banded sea bream (Diplodus vulgaris), and the black sea bream (Spondyliosoma cantharus). Time is the time in houts and minutes of the set in relation to sunrise, with negative values representing times before sunrise.

\begin{tabular}{|c|c|c|c|c|c|c|c|c|c|c|c|c|c|c|c|c|c|}
\hline \multicolumn{10}{|c|}{ Hook } & \multicolumn{8}{|c|}{ Species } \\
\hline \multirow[t]{2}{*}{ Type } & \multirow[t]{2}{*}{ Time } & \multicolumn{2}{|r|}{11} & \multicolumn{2}{|r|}{13} & \multicolumn{2}{|c|}{15} & \multicolumn{2}{|c|}{ Total } & \multicolumn{2}{|c|}{ P. acarne } & \multicolumn{2}{|c|}{ P. erythrinus } & \multirow{2}{*}{$\begin{array}{c}\begin{array}{c}\text { D. vul- } \\
\text { garis }\end{array} \\
\mathrm{n}\end{array}$} & \multirow{2}{*}{$\begin{array}{c}\begin{array}{c}\text { S. cantha- } \\
\text { rus }\end{array} \\
\mathrm{n}\end{array}$} & \multirow{2}{*}{$\frac{\text { 'red' }}{n}$} & \multirow{2}{*}{$\frac{\begin{array}{l}\% \\
\text { breams }\end{array}}{\text { Weight }}$} \\
\hline & & n & Weight & $\mathrm{n}$ & Weight & $\mathrm{n}$ & Weight & $\mathrm{n}$ & Weight & $\mathrm{n}$ & Weight & $\mathrm{n}$ & Weight & & & & \\
\hline $\mathrm{A}$ & $+0: 11$ & 29 & 354 & 22 & 3201 & 48 & 6394 & 99 & 14949 & 1 & 124 & 3 & 185 & 8 & 31 & 4.0 & 8.8 \\
\hline A & $+0: 01$ & 24 & 2129 & 33 & 3647 & 53 & 4613 & 110 & 10388 & 0 & 0 & 0 & 0 & 0 & 29 & 0.0 & 0.0 \\
\hline A & $-0: 04$ & 22 & 2348 & 48 & 4051 & 28 & 2793 & 98 & 9192 & 0 & 0 & 0 & 0 & 0 & 30 & 0.0 & 0.0 \\
\hline A & $-1: 06$ & 13 & 1947 & 12 & 1919 & 12 & 1324 & 37 & 5190 & 1 & 283 & 0 & 0 & 4 & 6 & 2.7 & 5.5 \\
\hline A & $-0: 59$ & 21 & 2251 & 30 & 3325 & 39 & 5225 & 90 & 10800 & 16 & 3325 & 2 & 841 & 6 & 7 & 20.0 & 38.6 \\
\hline A & $-0: 41$ & 8 & 1414 & 37 & 6069 & 27 & 4955 & 72 & 12437 & 4 & 900 & 4 & 1457 & 27 & 10 & 11.1 & 18.9 \\
\hline A & $+2: 12$ & 19 & 2886 & 10 & 1076 & 51 & 4168 & 80 & 8130 & 0 & 0 & 0 & 0 & 3 & 2 & 0.0 & 0.0 \\
\hline A & $-0: 47$ & 15 & 3056 & 29 & 5060 & 31 & 5189 & 75 & 13305 & 13 & 2627 & 4 & 1017 & 6 & 37 & 22.7 & 27.4 \\
\hline $\mathrm{A}$ & $-0: 49$ & 26 & 4417 & 34 & 5762 & 41 & 5934 & 101 & 16113 & 42 & 8736 & 0 & 0 & 3 & 19 & 41.6 & 54.2 \\
\hline A & $-0: 57$ & 22 & 6189 & 25 & 4482 & 26 & 4666 & 73 & 15337 & 27 & 5733 & 8 & 3403 & 3 & 7 & 47.9 & 59.6 \\
\hline A & $+1: 01$ & 24 & 5131 & 39 & 5327 & 56 & 8165 & 119 & 18623 & 0 & 0 & 1 & 360 & 4 & 50 & 0.8 & 1.9 \\
\hline A & $-1: 00$ & 11 & 1746 & 17 & 1938 & 40 & 5533 & 68 & 9217 & 11 & 2044 & 2 & 647 & 6 & 13 & 19.1 & 29.2 \\
\hline A & $-0: 24$ & 22 & 5275 & 24 & 3493 & 38 & 7009 & 84 & 15777 & 2 & 387 & 9 & 2758 & 25 & 13 & 13.1 & 19.9 \\
\hline A & $+0: 07$ & 17 & 3037 & 38 & 4966 & 43 & 4689 & 98 & 12692 & 3 & 404 & 2 & 625 & 4 & 23 & 5.1 & 8.1 \\
\hline A & $-1: 13$ & 17 & 3678 & 19. & 2647 & 32 & 4716 & 68 & 11041 & 3 & 523 & 6 & 2169 & 21 & 10 & 13.2 & 24.4 \\
\hline A & $-0: 57$ & 10 & 1355 & 17 & 2426 & 34 & 3822 & 61 & 7603 & 2 & 333 & 1 & 209 & 10 & 14 & 4.9 & 7.1 \\
\hline B & $-1: 04$ & 50 & 15321 & 91 & 21989 & 114 & 25708 & 255 & 63018 & 106 & 27381 & 22 & 14892 & 63 & 21 & 50.2 & 67.1 \\
\hline B & $-1: 30$ & 45 & 12215 & 75 & 16636 & 96 & 17552 & 216 & 46402 & 100 & 19828 & 14 & 8029 & 47 & 37 & 52.8 & 60.0 \\
\hline B & $-1: 31$ & 42 & 13721 & 59 & 12113 & 85 & 18061 & 186 & 43895 & 87 & 20211 & 13 & 8131 & 43 & 15 & 53.8 & 64.6 \\
\hline B & $-1: 12$ & 43 & 9707 & 83 & 16866 & 145 & 23343 & 271 & 49917 & 69 & 15059 & 9 & 4092 & 38 & 102 & 28.8 & 38.4 \\
\hline $\mathrm{C}$ & $-1: 47$ & 41 & 8673 & 78 & 19500 & 49 & 9723 & 168 & 37896 & 33 & 6875 & 9 & 7339 & 52 & 27 & 25.0 & 37.5 \\
\hline $\mathrm{C}$ & $-1: 50$ & 27 & 6547 & 74 & 12596 & 67 & 11538 & 168 & 30682 & 51 & 9846 & 15 & 5864 & 24 & 52 & 39.3 & 51.2 \\
\hline $\mathrm{C}$ & $-0: 04$ & 7 & 1077 & 39 & 6398 & 51 & 8145 & 97 & 15620 & 1 & 123 & 7 & 3425 & 4 & 47 & 8.2 & 22.7 \\
\hline $\mathrm{C}$ & $-1: 59$ & 16 & 2536 & 31 & 4972 & 42 & 6242 & 89 & 13749 & 39 & 8006 & 0 & 0 & 1 & 11 & 43.8 & 58.2 \\
\hline $\mathrm{C}$ & $-3: 04$ & 36 & 8098 & 57 & 13017 & 92 & 16802 & 185 & 37917 & 49 & 11326 & 11 & 4737 & 31 & 48 & 32.4 & 42.4 \\
\hline $\mathrm{C}$ & $-2: 16$ & 19 & 4484 & 23 & 5446 & 39 & 7935 & 81 & 17866 & 30 & 8341 & 6 & 3483 & 8 & 18 & 44.4 & 66.2 \\
\hline $\mathrm{C}$ & $-1: 24$ & 21 & 7326 & 45 & 8359 & 37 & 9760 & 103 & 25446 & 31 & 8502 & 22 & 10708 & 4 & 29 & 51.5 & 75.5 \\
\hline $\mathrm{C}$ & $-1: 28$ & 37 & 11425 & 68 & 15952 & 71 & 15959 & 176 & 43336 & 29 & 8777 & 18 & 9169 & 71 & 24 & 26.7 & 41.4 \\
\hline Total & & 684 & 153341 & 1157 & 213334 & 1487 & 249962 & 3328 & 16537 & 750 & 69967 & 188 & 94538 & 516 & 732 & & \\
\hline
\end{tabular}

Aquat. Living Resour. 11 (1) (1998) 
hook No. 15, 19.3 for hook No. 13 and 11.0 for hook No. 11.

The time of setting of the longline was critical; highest catch rates of 'red' sea breams were obtained during the time interval $1-2 \mathrm{~h}$ before sunrise (table II). Almost no Pagellus acarne were caught in sets made after sunrise. A significant number of sets in fishing trials $A$ were made after sunrise, while all the sets of trials $B$ and $C$ were before sunrise.

In 9 of 12 cases the null hypothesis that bait type has no effect on size distribution of the catch was clearly not rejected (table III). For Pagellus acarne, Pagellus erythrinus and Spondyliosoma cantharus caught with hook number 13 the critical values were slightly less than the two-tailed Kolmogorov-Smirnov statistic. Given these results, we decided to pool the data for the two different baits under the assumption that bait type did not have an effect on the catch size distribution for each hook size.

The estimated parameters for a selection of logistic and normal selectivity models for each species are given in tables $I V$ and $V$. Models which dit not give reasonable parameter estimates or failed to converge are not included in the tables.

Based on the likelihood function and Millar plots, the logistic model with all parameters linear functions of hook size was selected for further analysis for all four species. The observed catches and the expected

Table III. Results of the Kolmogorov-Smirnov test of independence of catch size distributions for two different baits, for the same hook size. Ho indicates that the null hypotheses was not rejected $(P>0.05)$. Decisions in parentheses are borderline.

\begin{tabular}{|c|c|c|c|c|c|c|}
\hline Species & Hook & $\begin{array}{l}\text { Sample size for } \\
\text { razor shell (n) }\end{array}$ & $\begin{array}{l}\text { Sample size for } \\
\text { mud shrimp (n) }\end{array}$ & $\begin{array}{l}\text { Two-tailed } \\
\text { K-S statistic }\end{array}$ & $\begin{array}{c}\text { Critical value } \\
\alpha=0.05\end{array}$ & Decision \\
\hline Diplodus vulgaris & $\begin{array}{l}11 \\
13 \\
15\end{array}$ & $\begin{array}{r}72 \\
133 \\
255\end{array}$ & $\begin{array}{r}7 \\
13 \\
35\end{array}$ & $\begin{array}{l}0.52 \\
0.24 \\
0.05\end{array}$ & $\begin{array}{l}0.54 \\
0.40 \\
0.25\end{array}$ & $\begin{array}{l}\text { Ho } \\
\text { Ho } \\
\text { Ho }\end{array}$ \\
\hline Pagellus acarne & $\begin{array}{l}11 \\
13 \\
15\end{array}$ & $\begin{array}{l}151 \\
228 \\
225\end{array}$ & $\begin{array}{r}24 \\
225 \\
62\end{array}$ & $\begin{array}{l}0.27 \\
0.14 \\
0.17\end{array}$ & $\begin{array}{l}0.30 \\
0.13 \\
0.20\end{array}$ & $\begin{array}{c}\text { Ho } \\
\text { (Ha) } \\
\text { Ho }\end{array}$ \\
\hline Pagellus erythrinus & $\begin{array}{l}11 \\
13 \\
15\end{array}$ & $\begin{array}{l}56 \\
34 \\
42\end{array}$ & $\begin{array}{l}20 \\
12 \\
23\end{array}$ & $\begin{array}{l}0.17 \\
0.48 \\
0.19\end{array}$ & $\begin{array}{l}0.35 \\
0.46 \\
0.35\end{array}$ & $\begin{array}{c}\mathrm{Ho} \\
(\mathrm{Ha}) \\
\mathrm{Ho}\end{array}$ \\
\hline Spondyliosoma cantharus & $\begin{array}{l}11 \\
13 \\
15\end{array}$ & $\begin{array}{l}123 \\
236 \\
316\end{array}$ & $\begin{array}{r}6 \\
29 \\
21\end{array}$ & $\begin{array}{l}0.26 \\
0.27 \\
0.10\end{array}$ & $\begin{array}{l}0.57 \\
0.27 \\
0.31\end{array}$ & $\begin{array}{c}\text { Ho } \\
\text { (Ho) } \\
\text { Ho }\end{array}$ \\
\hline
\end{tabular}

Table IV. Estimated parameters and likelihood function for the logistic selectivity curve fitted by maximum likelihood. H, maximum hook size; b determines the slope of the logistic curve; L50, size at $50 \%$ selection.

\begin{tabular}{|c|c|c|c|c|}
\hline Species & $\begin{array}{c}Q \\
\text { (Scaling factor) }\end{array}$ & b & L50 & $\begin{array}{c}\text { Likelihood } \\
\text { function }\end{array}$ \\
\hline D. vulgaris & - & $7.45 \times 10^{-4} \mathrm{H}+1.23$ & $\begin{array}{l}129 \times 10^{-4} \mathrm{H}+19.55 \\
115 \times 10^{-4} \mathrm{H}+20.07\end{array}$ & $\begin{array}{l}-452.95 \\
-452.89\end{array}$ \\
\hline P. acarne & - & $14.93 \times 10^{-4} \mathrm{H}+0.04$ & $-255.89 \times 10^{-4} \mathrm{H}+15.32$ & -804.78 \\
\hline P. erythrinus & $\begin{array}{c}- \\
- \\
27.43 \times 10^{4} \mathrm{H}+1.02\end{array}$ & $\begin{array}{c}1.02 \\
28.89 \times 10^{-4} \mathrm{H}+7.27 \\
28.63 \times 10^{-4} \mathrm{H}+7.82\end{array}$ & $\begin{array}{r}0.49 \times 10^{-4} \mathrm{H}+31.30 \\
9.67 \times 10^{-4} \mathrm{H}+30.05 \\
-7.01 \times 10^{-4} \mathrm{H}+29.98\end{array}$ & $\begin{array}{l}-205.44 \\
-200.94 \\
-200.15\end{array}$ \\
\hline S. cantharus & $\begin{array}{c}- \\
- \\
27.08 \times 10^{-4} \mathrm{H}+0.83\end{array}$ & $\begin{array}{c}0.40 \\
-3.52 \times 10^{-4} \mathrm{H}+0.51 \\
-2.69 \times 10^{-4} \mathrm{H}+0.44\end{array}$ & $\begin{array}{c}406.80 \times 10^{-4} \mathrm{H}+10.11 \\
418.29 \times 10^{-4} \mathrm{H}+9.62 \\
27.08 \times 10^{-4} \mathrm{H}+0.83\end{array}$ & $\begin{array}{l}-743.06 \\
-743.04 \\
-742.78\end{array}$ \\
\hline
\end{tabular}

Table V. Estimated parameters and likelihood function for the logistic selectivity curve fitted by maximum likelihood. $\mathrm{H}$, maximum hook size; SD, standard deviation of the mean length $(\mathrm{cm})$.

\begin{tabular}{lcrrr}
\hline Species & $\begin{array}{c}Q \\
\text { (Scaling factor) }\end{array}$ & $\begin{array}{c}\text { SD } \\
(\mathrm{cm})\end{array}$ & $\begin{array}{c}\text { Length (mean) } \\
(\mathrm{cm})\end{array}$ & $\begin{array}{c}\text { Likelihood } \\
\text { function }\end{array}$ \\
\hline D. vulgaris & - & $-10.52 \times 10^{-4} \mathrm{H}+1.96$ & $65.10 \times 10^{-4} \mathrm{H}+24.13$ & -451.87 \\
& $-0.43 \times 10^{-4} \mathrm{H}+1.09$ & $-10.51 \times 10^{-4} \mathrm{H}+1.95$ & $65.28 \times 10^{-4} \mathrm{H}+24.11$ & -451.87 \\
P. acarne & - & $-87.89 \times 10^{-4} \mathrm{H}+12.06$ & $589.00 \times 10^{-4} \mathrm{H}+15.59$ & -806.95 \\
P. erythrinus & - & $-0.30 \times 10^{-4} \mathrm{H}+0.85$ & $6.37 \times 10^{-4} \mathrm{H}+28.10$ & -201.91 \\
& $-0.37 \times 10^{-4} \mathrm{H}+1.37$ & $-0.06 \times 10^{-4} \mathrm{H}+0.46$ & $2.32 \times 10^{-4} \mathrm{H}+28.25$ & -201.11 \\
S. cantharus & $0.64 \times 10^{-4} \mathrm{H}^{2}-1.13 \times 10^{-4} \mathrm{H}+0.98$ & $-0.06 \times 10^{-4} \mathrm{H}+0.48$ & $2.12 \times 10^{-4} \mathrm{H}+28.02$ & -201.90 \\
\hline
\end{tabular}


catches based on these models are given in figures 3-6. As can be seen, good fits were obtained for all the four species. This was confirmed by the results of $\chi^{2}$ test (table VI). The logistic selectivity curves for Diplodus vulgaris, Pagellus acarne, Pagellus erythrinus and Spondyliosoma cantharus are shown in figure 7.

\section{DISCUSSION}

Five species of Sparidae clearly dominated the catches, with the two 'red' sea breams Pagellus acarne and Pagellus erythrinus particularly important in weight and value. As in the previous longline selectiv-
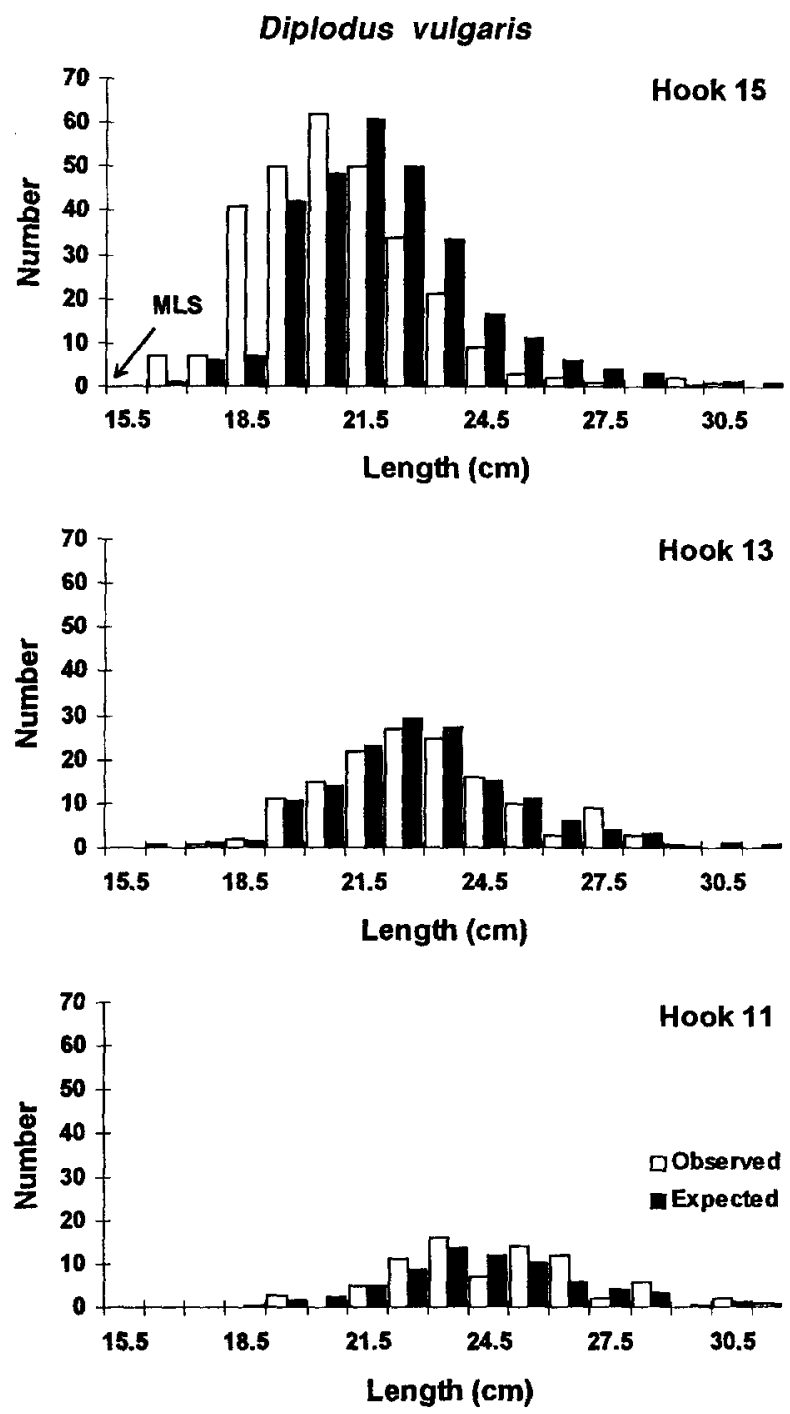

Figure 3. Comparison of the observed and predicted catch length frequency distributions for the three hook sizes according to the logistic selectivity model for Diplodus vulgaris. MLS is the minimum legal size (total length).
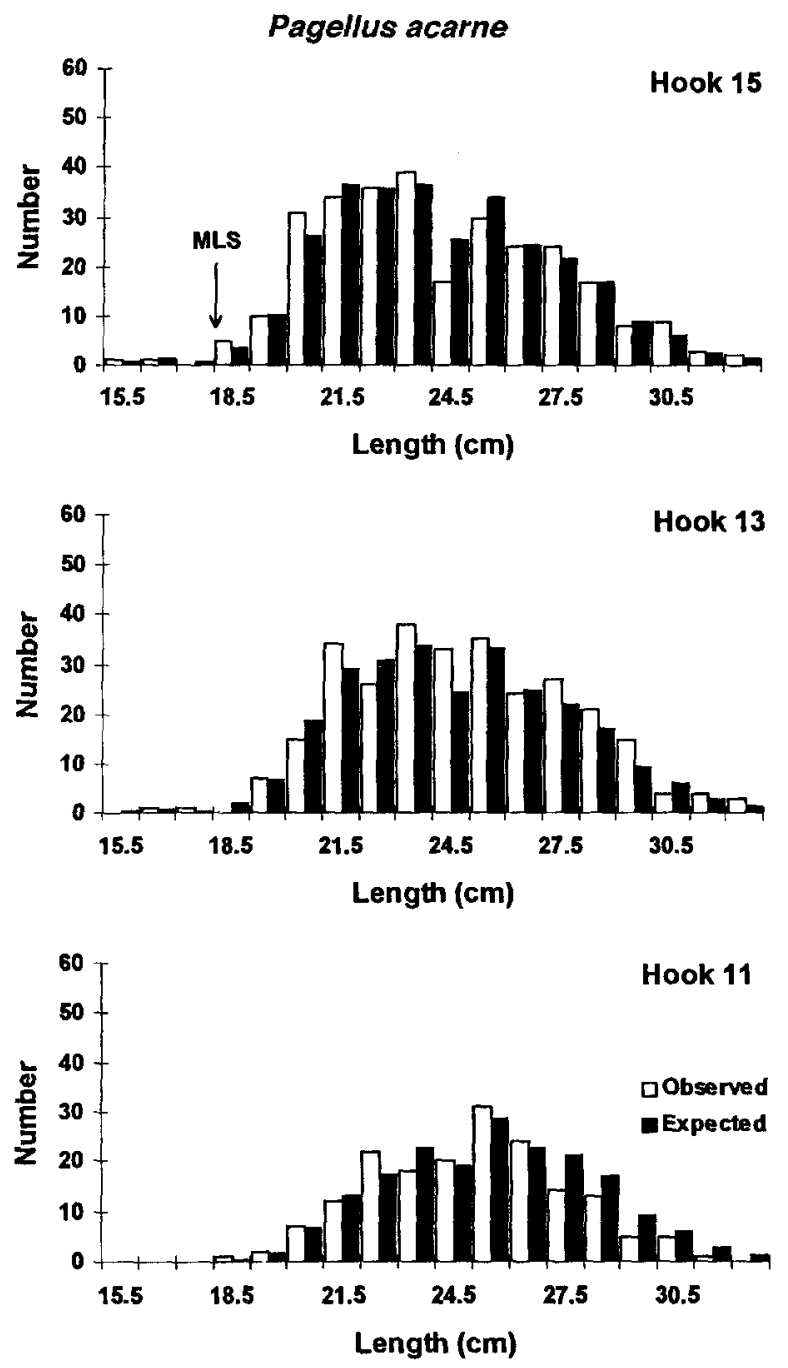

Figure 4. Comparison of the observed and predicted catch length frequency distributions for the three hook sizes according to the logistic selectivity model for Pagellus acarne. MLS is the minimum legal size (total length).

ity study, there was a marked decrease in overall catch rate with increasing hook size, suggesting that there is a limited range in effective or appropriate hook size in this fishery. For Pagellus erythrinus, the differences between the hooks in terms of catch rate were not as conclusive given the smaller number of fish caught overall. However, the catch rate for the largest hook (number 11) was greater than for the smaller hooks.

In general, the catch size distributions were highly overlapped, with all hook sizes catching a wide range of fish sizes. This may be due to a combination of factors. First, these are mainly small species with maximum reported sizes of less than $50 \mathrm{~cm}$ TL in most cases. The exceptions are Pagellus erythrinus and 
Pagellus erythrinus
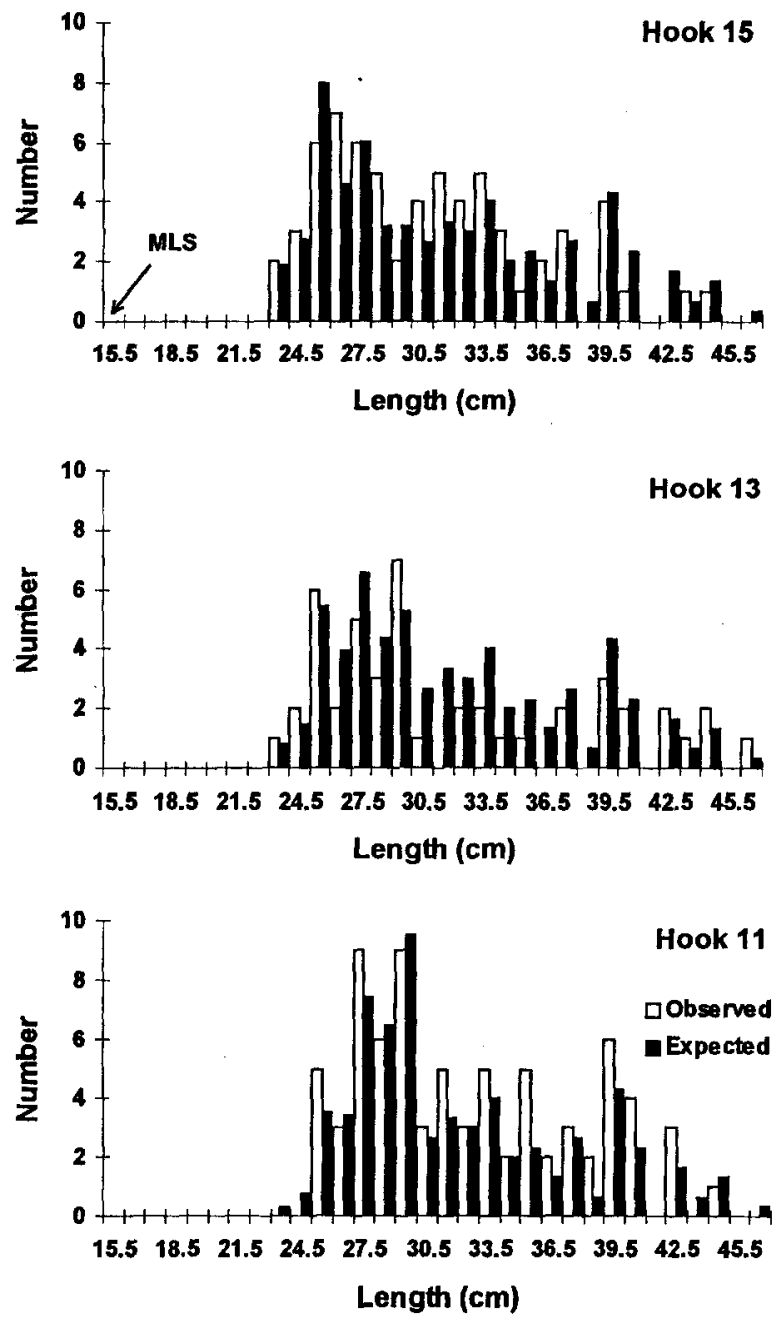

Figure 5. Comparison of the observed and predicted catch length frequency distributions for the three hook sizes according to the logistic selectivity model for Pagellus erythrinus. MLS is the minimum legal size (total length).

Spondyliosoma cantharus which have reported maximum sizes of $60 \mathrm{~cm}$. However, Spondyliosoma cantharus do not attain these sizes in the south of Por-
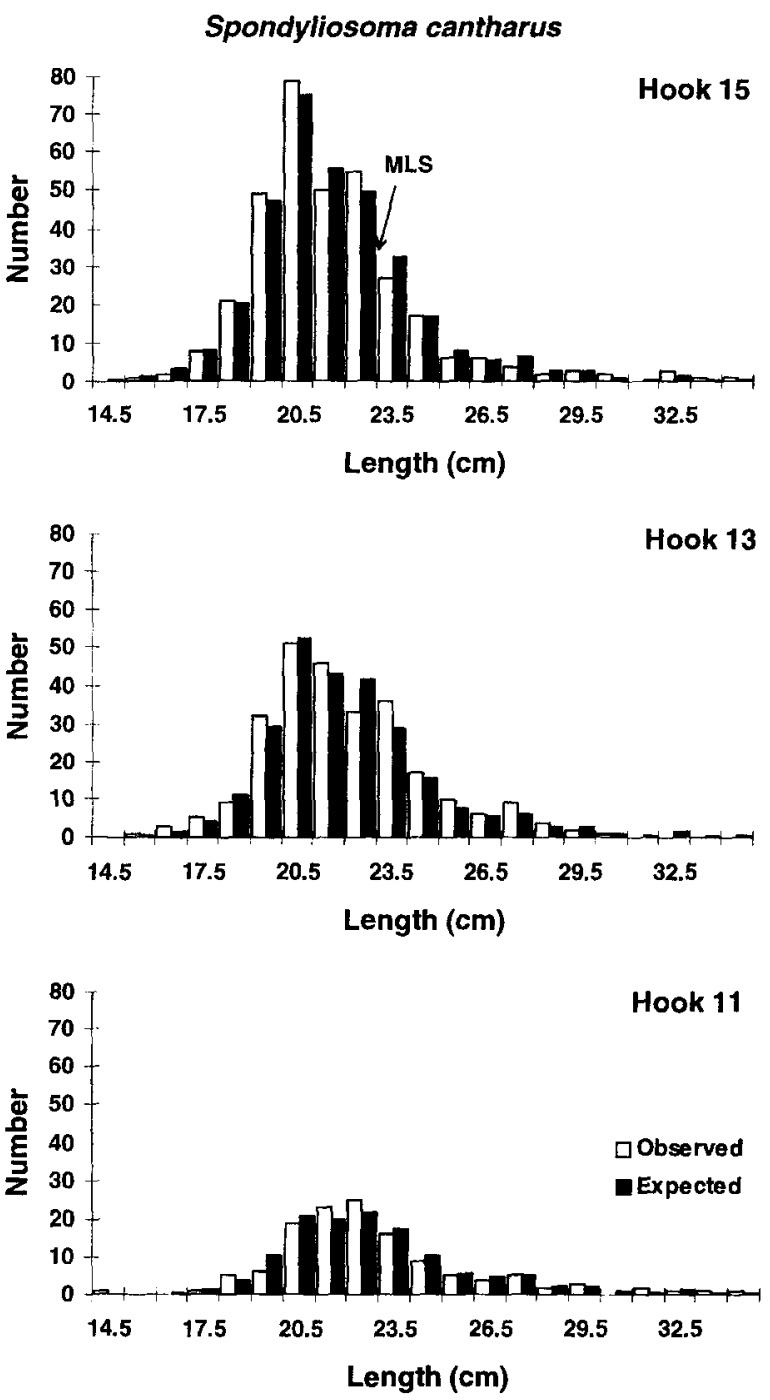

Figure 6. Comparison of the observed and predicted catch length frequency distributions for the three hook sizes according to the logistic selectivity model for Spondyliosoma cantharus. MLS is the minimum legal size (total length).

tugal $[4,7,8]$, and it can be safely assumed that Pagellus erythrinus greater than $50 \mathrm{~cm}$ are exceedingly rare, due to the high exploitation rates prevailing. Thus, this

Table VI. Results of the $\chi^{2}$ test of goodness of fit (observed and expected values) for logistic selectivity models fit to the four main species. c, number of pairs of observed and expected catches; $r$, number of pairs of observed and expected catches in case of size classes; $v$, number of parameters in the model; df, degree of freedom.

\begin{tabular}{|c|c|c|c|c|c|c|c|c|}
\hline Species & Model & $\mathrm{c}$ & r & $\mathrm{v}$ & $\underset{(c-t-v)}{\mathrm{df}}$ & $\begin{array}{c}\chi^{2} \\
\text { obs. }\end{array}$ & $\begin{array}{c}\chi^{2} \\
(\alpha=0.05)\end{array}$ & Decision \\
\hline Diplodus vulgaris & Logistic & 27 & 11 & 4 & 12 & $19 . \overline{18}$ & 21.03 & Accept Ho \\
\hline Pagellus acarne & Logistic & 36 & 13 & 4 & 19 & 28.08 & 30.14 & Accept Ho \\
\hline Pagellus erythrinus & Logistic & 21 & 7 & 4 & 10 & 16.50 & 18.31 & Accept Ho \\
\hline Spondyliosoma cantharus & Logistic & 35 & 13 & 4 & 18 & 18.09 & 28.87 & Accept Ho \\
\hline
\end{tabular}


(a) Diplodus vulgaris

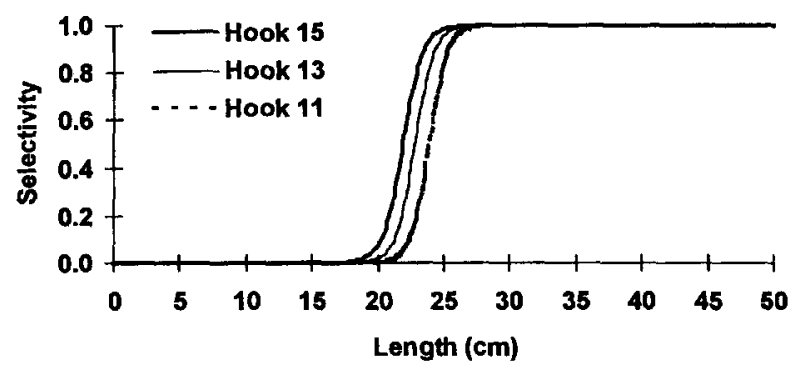

(b) Pagellus acarne

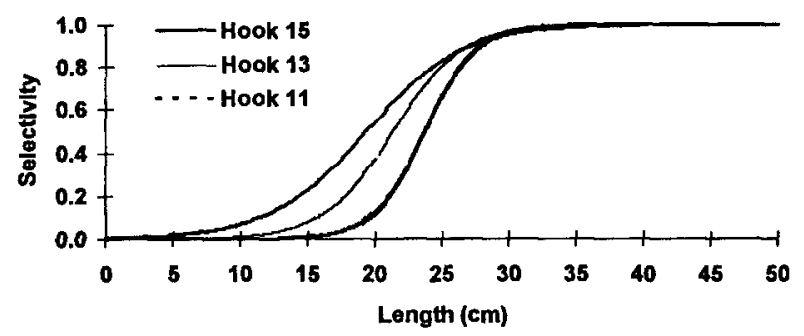

(c) Pagellus erythrinus

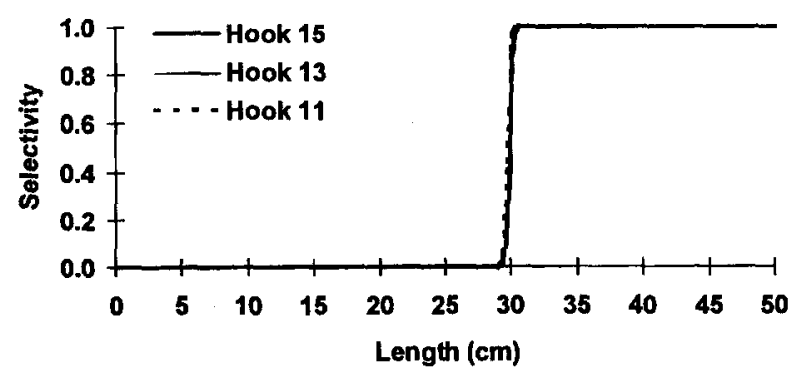

(d) Spondyliosoma cantharus

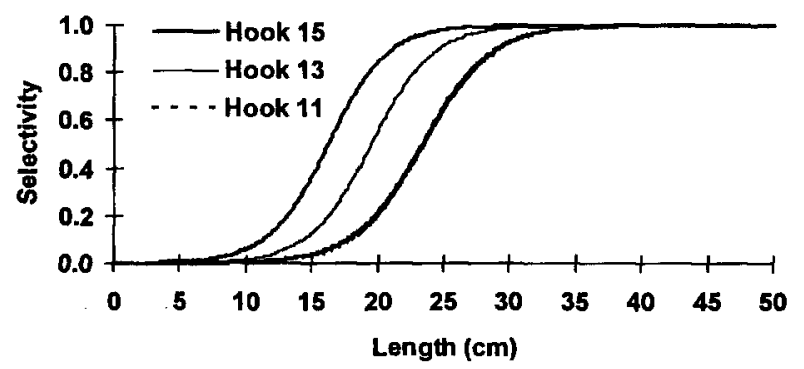

Figure 7. Logistic selectivity curves for Diplodus vulgaris, Pagellus acarne, Pagellus erythrinus and Spondyliosoma cantharus.

fishery is based on fish populations with a fairly limited size. Consequently, intra-species variation in mouth size and feeding habits is small. This may be a major reason for the observed differences in size selectivity of the different hook sizes. Secondly, the hooks used in this study did not differ greatly in size. The overall size (max. width $\times$ max. length) of the largest hook was 2.09 times that of the smallest hook.

In other cases selectivity has only been demonstrated using hooks differing in overall size by more than $200 \%$, with characteristically highly overlapped catch distributions. This is particularly true for small species with a relatively narrow size range such as the spiny goby, Acanthogobius flavimanus [18, 27], pond smelt, Hypomesus olidus [18], and chub mackerel, Scomber japonicus [14]. In general, these studies have shown that efficiency decreases with increasing hook size and all hook sizes catch a similar range of sizes. Some studies have concluded that there was no difference in selectivity $[23,1]$. In these two studies the largest hooks were $72 \%$ and $96 \%$ bigger than the smallest. Thus the apparent lack of selectivity in our study may be due to the fairly limited size range of hooks.

Other studies of hook selectivity have used a wide range of sizes and types of hooks and have come to different conclusions. For example, hook size selectivity was reported for the yellowfin tuna (Thunnus albacares) [6] using a series of hook sizes with gapes ranging from 1.2 to $2.9 \mathrm{~cm}$. Three sizes of 'Mustad' tuna hooks were used to evaluate selectivity in the sea bream Pagrus auratus were used [20]. With overall hook size differences of only 26.5 and $65 \%$ they found that the smallest hook caught more illegal sized fish $(<25 \mathrm{~cm}$ FL) while the largest hook caught relatively more bigger fish. All three hooks caught fish ranging in size from less than $20 \mathrm{~cm}$ to more than $60 \mathrm{~cm}$, and efficiency decreased with increasing hook size.

Many different types of models have been proposed or used in hook selectivity studies $[5,3,13,18,27,22$, $14,17,23,24,21,6,7,8]$, including normal, skewnormal, and logistic. Since there is no clear consensus regarding the appropriate model or models for hook and line gear, exploratory plots can be used as an aid in choosing the selectivity model to fit $[24,15,19]$. Plots of the ratios of catches or proportions of observed catches of different sized hooks by size class against size class result in characteristic patterns which can be diagnostic for the underlying selectivity model fit $[24$, $15,19]$.

In this study, exploratory plots of the observed catch proportions [19] were found to be useful for choosing the appropriate selecitivity models. However, because of the considerable overlapping of the catch size distributions for the three hook sizes for all species, some difficulty was found in the fitting of the selectivity curves. This is because the methodology used assumes that parameters of the chosen selectivity curves are a function of hook size. For example, the means of normal selectivity curves may be linear functions of hook size. However, in highly overlapped distributions, the differences in the means may be minimal and/or unrelated to hook size. Also, the lack of smaller fish was reflected in truncated catch distributions for Pagellus erythrinus, resulting in steep selectivity curves. The 
use of only three hook sizes may also have contributed to this difficulty. Based on our experience in this project and the previous one, we recommend the use of at least four hook sizes in selectivity studies.

In most cases both types of selectivity curves gave similarly good fits. This is not surprising given the limited size range and the shapes of the catch frequency distributions for most species in this fishery and is in agreement with the previous findings [19]. However, based on the exploratory Millar plots and our own fishing experience, we believe that logistic-type selectivity is in fact more appropriate for small-sized species such as these. The exception may be Pagellus erythri- $n u s$, where for the very largest individuals we might expect decreased selectivity for the smallest hooks such as the number 15 . In this case an asymptotic curve with decreasing selectivity at the upper end of the size range may be more appropriate.

With the exception of Spondyliosoma cantharus, capture of illegal-sized fish is minimal even for the smallest-sized hook. For some species such as Pagellus erythrinus no fish smaller than the minimal legal size were caught. In terms of conservation or resources, the longline is a gear which has many beneficial aspects and should perhaps be promoted as an alternative to more destructive gears.

\section{Acknowledgements}

This study was funded in part by the Commission of the European Communities (DG, XIV, Project ref. 94/059). We would like to thank all the Praia de Faro fishermen who were involved in this project and the many colleagues who helped with the sampling, in particular, Paulo Vilia, Pedro Monteiro, and Henry Vischer. We would also like to thank Dr Kostas Stergiou and three other anonymous referees whose suggestions greatly improved the manuscript.

\section{REFERENCES}

[1] Bertrand J., Selectivity of hooks in the handline fishery of the Saya de Malha Banks (Indian Ocean), Fish Res. 6 (1988) 249-255.

[2] Bjordal §., Løkkeborg Longlining S, Fishing New Books, 1996, $156 \mathrm{p}$.

[3] Brock V.E., On the nature of the selective fishing action of longline gear, Pac. Sci. 16 (1962) 3-14.

[4] Canário A.V.M., Erzini K., Castro M., Gonçalves J.M.S., Galhardo C., Ribeiro J., Bentes L., Cruz J., Souto P., Estudos base para a conservação dos ictiopovoamentos e gestão da pesca costeira no litoral Sudoeste, Faro, UAL-UCTRA/SNPRCN-APPSACV (1994) $219 \mathrm{p}$.

[5] Clark J.R., Report on selectivity of fishing gear, in: Fishing effort, the effect of fishing on resources and the selectivity of fishing gear, ICNAF Spec. Publ. 2 (1960) 27-36.

[6] Cortez-Zaragoza E., Dalzell P., Pauly D., Hook selectivity of yellowfin tuna (Thunnus albacares) caught off Darigayos Cove, La Union, Philippines, J. Appl. Ichthyol. 1 (1989) 12-17.

[7] Erzini K., Gonçalves J.M.S., Bentes L., Lino P.G., Small hook longline selectivity study. Final Report, Commission of the European Communities, DG XIV/ C/1, Ref. BIOECO 93/004 (1995) 62 p. + appendices

[8] Erzini K., Gonçalves J.M.S., Bentes L., Lino P.G., Cruz J., Species and size selectivity in a Portuguese multispecies artisanal long-line fishery, ICES J. Mar. Sci. 53, 1996, pp. 811-819.

[9] Erzini K., Santos M.N., Monteiro C.C., Gonçalves J.M.S., Bentes L., Lino P.G., A comparison of species and size selectivity of monofilament gillnets and small hook longlines. Naga, ICLARM Quarterly 19 (1966) 29-32.

[10] Erzini K., Gonçalves J.M.S., Bentes L., Lino P.G., Mouth size and hook selectivity in a multispecies artisanal longline fishery, J. Appl. Ichthyol. 13 (1997) 41-44.

[11] Erzini K., Gonçalves J.M.S., Bentes L., Lino P.G. Ribeiro J., Longline selectivity and biology of 'red' sea breams (Sparidae). Final Report, Commission of the European Communities DG XIV/C/1, Ref. 94/059, 1997, 100 p. + appendices.

[12] Hartman W.M., The NLP Procedure: Release 6.10. Extended User's Guide. SAS Institute, Inc. 325 p.

[13] ICNAF, The selectivity of fishing gear, Int. Comm. Northwest Atl. Fish., Spec. Publ. Vol. 5, 1963, 225 p.

[14] Kanda K., Koike A., Takeuchi S., Ogura M., Selectivity of the hook of mackerel, Scomber japonicus Houttuyn, pole fishing, J. Tokyo Univ. Fish. 64 (1978) 109-114.

[15] Kenchington T.J., Estimation of the functional form of selectivity by baited hooks: a graphical approach, Can. J. Fish. Aquat. Sci. 50 (1993) 772-780.

[16] Kirkwood G.P., Walker T.I., Gill net selectivities for gummy shark, Mustelus antarcticus Günther, taken in south-eastern Australian waters, Austr. J. Mar. Freshw. Res. 37 (1986) 689-697.

[17] Koike A., Kanda K., Selectivity of the hook of pond smelt, Hypomesus olidus, J. Tokyo Univ. Fish. 64 (1978) 115-123.

[18] Koike A., Takeuchi S., Ogura M., Kanda K., Arihara C., Selection curve of the hook of long line, J. Tokyo Univ. Fish. 55 (1968) 77-82.

[19] Millar R.B., The functional form of hook and gillnet selection curves cannot be determined from comparative catch data alone, Can. J. Fish. Aquat. Sci. 52 (1995) 883-891. 
[20] Otway N.M., Craig J.R., Effects of hook size on the catches of undersized snapper Pagrus auratus, Mar. Ecol. Prog. Ser. 93 (1993) 9-15.

[21] Pavez P.C. Oyarzún M.E.F., Determinación de eficiencia relativa de espineles y parámetros de crecimiento del bacalao de Juan Fernández (Polyprion oxygeneios Bloch y Schneider, 1801), en las islas Robinson Crusoe y Santa Clara, in: Investigaciones marina en el Archipiélago de Juan Fernandez, P. Arana (ed.), Valparaison, Escuela de Ciencias del Mar, UCV, 1985, pp. 323-340.

[22] Pope J.A., Margetts A.R., Hamley J.M., Aykuz E.F., Manual of methods for fish stock assessment. Part III. Selectivity of fishing gear, FAO Fish. Tech. Pap. 41 (Rev. 1), 1975, $46 \mathrm{p}$.

[23] Ralston S., Influence of hook size in the Hawaiian deepdea handline fishery, Can. J. Fish. Aquat. Sci. 39 (1982) 1297-1302.
[24] Ralston S., Size selection of snappers (Lutjanidae) by hook and line gear, Can. J. Fish. Aquat. Sci. 47 (1990) 696-700.

[25] Saila S.B., Erzini K., An improved method for fitting gillnet selectivity curves to predetermined distributions. Fisheries Stock Assessment. Title XII, Collaborative Research Support Program 43, 1989, 29 p.

[26] Siegel S., Castellan N.J., Nonparametric statistics for the behavioral sciences, Statistics Series, 2nd Edition, McGraw-Hill, New York, 1988, 399 p

[27] Takeuchi S., Koike A., The effect of size and shape of hook on the catching efficiency and selection curve of long-line, J. Tokyo Univ. Fish. 55 (1969) 119-124.

[28] Wulff A., Mathematical model for selectivity of gill nets, Arch. Fish. Wiss. 37 (1986) 101-106. 